
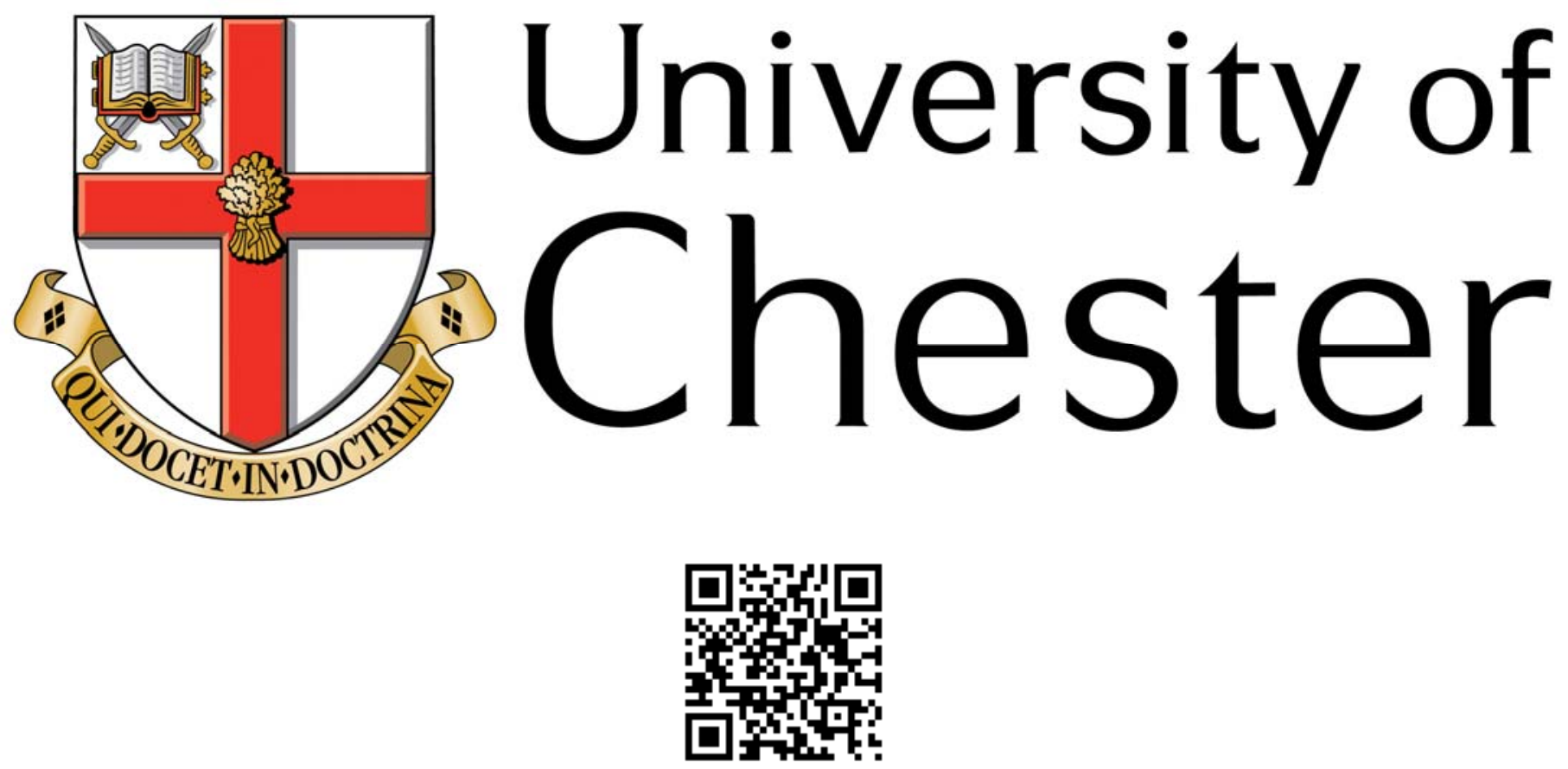

This work has been submitted to ChesterRep - the University of Chester's online research repository

\title{
http://chesterrep.openrepository.com
}

Author(s): Elaine L Graham

Title: Doing God? Public theology under Blair

Date: 2009

Originally published in: Remoralising Britain? Political, ethical and theological perspectives on New Labour

Example citation: Graham, E.L. (2009). Doing God? Public theology under Blair. In P.M. Scott, C.T.H. Baker, \& E.L. Graham (Eds.), Remoralising Britain? Political, ethical and theological perspectives on New Labour (pp. 1-18). London, United Kingdom: Continuum.

Version of item: Author's post-print

Available at: http://hdl.handle.net/10034/236588 


\section{Doing God? Public Theology under Blair}

God and New Labour: A Joke or an Enigma?

One of the most enduring portrayals of Tony Blair during his Premiership was that depicted in Private Eye magazine, of 'the Revd. A.R.P. Blair', vicar of 'St. Albion's Parish Church'. Its representation was of Tony the trendy vicar, full of cheerful sincerity, guitar at the ready, instructing his flock with worthy homilies on education or the Third Way or extolling the virtues of the ecumenical alliance with "Revd Dubya Bush of the Church of the Latter-Day Morons". The column derived its satirical effect from its readers' knowledge that Blair's Christian faith was a key part of what defined him as an individual and a politician; but it also demonstrates the sense in which it was one of the most definitive and yet enigmatic aspects of his political personality. Blair himself made no secret of his faith, especially during his time as Leader of the Opposition, as New Labour worked to articulate its distinctive vision; in later years, however, flanked by advisers reluctant to 'do God', he seemed more diffident about being drawn into explicit statements of belief or conviction.

Yet despite this common knowledge of Blair's Christian profession, few evaluations of the Blair years have devoted serious or sustained attention to this 
dimension, or move much beyond the comic or the speculative. ${ }^{1}$ One exception was Anthony Seldon's political biography, Blair, which is organized around a series of chapters listing Blair's leading influences and protagonists, and dedicates one such chapter to 'God'. ${ }^{2}$ Yet disappointingly Seldon's latest and long-awaited edited collection, surveying the impact of New Labour between 1997 and 2007, contains no references to religion, Christianity or the church and only one on "Islam". ${ }^{3}$ This is a startling omission, but demonstrates, perhaps, that political commentators are by and large as unaccustomed to 'doing God' as some political spin-doctors.

${ }^{1}$ The latest in this latter category being the revival at the end of 2007 of the persistent rumours predicting Blair's imminent admission into the Roman Catholic Church. See Times, Guardian 9/11/07. When news of his eventual confirmation just before Christmas 2007 was announced it was hardly unexpected, therefore, despite media attempts to portray it otherwise. ${ }^{2}$ London, Free Press, 2004, pp. 515-532. See also Chapman, Mark (2005), Blair's Britain. London: Darton, Longman and Todd, which offers a critique of New Labour's appropriation of moral and religious discourse from a theological, and specifically a Christian socialist, perspective.

${ }^{3}$ Seldon, Anthony, ed. (2007), Blair's Britain 1997-2007. Cambridge: Cambridge University Press. 
Startling, then, but not surprising, given the generally secular nature of British public life at the beginning of the twenty-first century, and given that Blair's references to religion, God and moral values in public nevertheless take place in a country where active participation in organized religion and the currency of Christian discourse is one of the lowest in the Western world. But the very incongruity of Blair's personal religious convictions in relation to the largely secular trajectory of British public life of itself justifies critical attention. The fact is, the relationship between God and New Labour is not restricted to the private devotions of one former leader since Blair's successor, Gordon Brown, has frequently alluded to the formative influence of his upbringing within the Church of Scotland, going so far as to quote words from the New Testament in his first party conference speech as leader ${ }^{4}$.

Any analysis of the relationship between faith and politics in the Blair years, therefore, cannot simply be restricted to the personal convictions of one person. Nor can they be dismissed as irrelevant vestiges of superstition in an age of

\footnotetext{
${ }^{4}$ Brown, Gordon (2007), Courage: Eight Portraits. London: Bloomsbury; Wintour, Patrick (2007), “I will not let Britain down”', Guardian (25 September), online, http://www.guardian.co.uk/frontpage/story/0,2176532,00.html [30/09/07]. For a perspective challenging the connection between Brown's political convictions and religion, however, see Doug Gay, this volume.
} 
reason, since their very public currency attests to their ability to speak across the barriers of religious decline and cultural diversity. Yet what exactly do they represent as forms of public intervention into British political culture? It is one of the contentions of this volume that this lack of critical, informed and non-partisan attention to one of the defining elements of New Labour over the past decade is to 'bracket out' a significant dimension of the influences at work in British public life over the past decade.

To ask how 'faith' has been assimilated into the New Labour project, therefore, and how that has been mobilised as part of a moral project, we must insist on that being a matter of public discourse and not just private dispositions. Whilst the personal convictions of political leaders are intriguing, not least as weather vanes of wider public sensibilities - in terms of what can be professed in public, and in what terms - this is also an issue about the legitimacy of religious belief and practice in the public sphere. However, since the new visibility of religion goes against the grain of religion as conceived, culturally speaking, as something best kept private, so this article will examine the conventional wisdom that liberal democracy requires the maintenance of a neutral, secular, value-free public domain and the corresponding 'privatization' of religion, as well as indicating how the so-called 'secularisation thesis' has been displaced as the dominant narrative of modernity. I will also review some possible frameworks by which the reappearance of religion in public life might be evaluated. 


\section{On 'Doing God'}

New Labour's invocation of the language of morality has been a major defining characteristic of its political agenda. Much of its reinvention after eighteen years in opposition was conceived in terms of a new moral vision at the heart of British politics: the task of 'remoralising Britain'. The party represented itself as restoring moral rectitude to government through its ambitions for an ethical foreign policy; the championing of social inclusion and the merits of active citizenship; and promoting the virtues of education and self-improvement. Latterly, the 'war on terror' has assumed the status of a moral crusade in defence of Western democracy. ${ }^{5}$ The government has also been anxious to mobilise faith-based organizations as part of the so-called 'third sector' in projects of neighbourhood renewal and regeneration, and yet may have more ambitious plans in terms of deploying the resources of religious groups in the restructuring of the welfare state $^{6}$

${ }^{5}$ See this volume, Chaps ..

${ }^{6}$ During 2007 no fewer than three government departments - the Treasury, the Department of Work and Pensions and the Department of Communities and Local Government - have published reports on the role of the 'third sector' in the delivery of welfare provision, social services and economic and social regeneration. See Blitz, James and Hall, Ben (2007), Brown to press on with 
This has manifested itself more recently as a search for a common language by which to articulate and construct concepts of national identity, the rights and responsibilities of citizenship and the roots of social cohesion. This seems set to continue under Gordon Brown with his talk of 'Britishness'. Anthony Giddens' Foreword to this volume indicates how much of public debate in the UK about multi-culturalism lacks conceptual or practical precision, however.

Yet if the past decade has been about 'remoralising Britain' then we need to identify the genesis of that agenda. It is possible that it needs to be located in the late 1970s rather than the 1990s. Politics not simply as governance or management but as moral crusade, intended to transform British culture and the hearts and minds of the electorate, did not begin with New Labour. The turn to faith and morality over the past decade followed an earlier trend of so-called 'conviction politics' in the 1980s under Margaret Thatcher. Often attributed to a reaction to post-war 'Butskellite' political consensus, the Conservative administrations of the 1980s and early 1990s advocated not only a clear reformist manifesto but a distinctive moral vision. Much of that was directed towards reversing the tide of

\begin{tabular}{llllll}
\hline welfare & reforms. Financial Times & March 2 & (online),
\end{tabular}
http://www.ft.com/cms/s/2ac75c26-c863-11db-9a5e-000b5df10621.html [accessed 27/06/07] 
liberalism in matters of sexual behaviour and personal morality associated with the 1960s. Nor was Mrs. Thatcher averse to deploying moral and religious language in the pursuit of her political vision, from her misquoting of the prayer of St. Francis on the day of her election to the so-called 'Sermon on the Mound', delivered in May 1988 to the Church of Scotland General Assembly at New College, Edinburgh. ${ }^{7}$ Henry Clark's Church under Thatcher ${ }^{8}$ - after which I have titled this paper - shows how those years were in many respects a struggle over values, and how the churches, especially the Church of England, found themselves cast in the role of unofficial opposition to the government when many other institutions of civil society were weakened.

The election of John Smith as leader of the Labour Party in 1992 ushered in a new era of a more explicitly values-based politics. It saw the introduction of appeals to a legacy of 'ethical socialism' (with R.H. Tawney the most frequently invoked) with the reconstruction of New Labour after nearly two decades in opposition, and the need to rejuvenate core policy away from the extremes of welfare

\footnotetext{
${ }^{7}$ Raban, Jonathan (1989), God, Man and Mrs. Thatcher. London: Chatto Counterblasts No. 1 .

${ }^{8}$ Clark, Henry (1993), The Church Under Thatcher. London: SPCK.
} 
centralism or free market individualism. ${ }^{9}$ The revival of the Labour party after two decades of opposition was achieved partly through a rejuvenation of core principles, most particularly the relationship between the state and the individual and the renewal of the precepts of democratic socialism. And for Smith, and those around him, those values were those of Christian socialism, and were articulated in a series of lectures and publications over the next few years of Labour's period of opposition, which extended beyond Smith's death in 1994 and the accession of Blair to party leader.

Whilst Tony Blair was not alone in articulating the foundations of his political convictions in terms of religious values - and specifically a form of Christian socialism - he was one of the most articulate and prominent bearers of a new moral discourse within the Labour party's process of reorientation in the early 1990s. Writing a Foreword to a collection of sermons and speeches by leading Labour politicians and published by the Christian Socialist Movement, Blair argued for the reconsideration of the party's core values in these terms:

\footnotetext{
${ }^{9}$ Ormrod, David ed. (1990), Fellowship, Freedom and Equality. London: Christian Socialist Movement; Bryant, Chris ed. (1993), Reclaiming the Ground: Christianity and Socialism. London: Hodder \& Stoughton; Haslam, David and Dale, Graham eds (2001), Faith in Politics. London: Christian Socialist Movement.
} 
By rethinking and re-examining our values, and placing them alongside those of the Christian faith, we are able, politically, to rediscover the essence of our beliefs which lies not in policies or prescriptions made for one period of time, but in principles of living that are timeless. By doing so, we can better distinguish between values themselves and their application, the one constant and unchanged, the other changing constantly. To a Labour Party now undertaking a thorough and necessary analysis of our future, this is helpful. ${ }^{10}$

The appropriation of the moral vocabulary of Christian socialism may have been due to a combination of internal and external factors: a search for less politically fractious political principles as a way of renewing Labour's wider electoral appeal; a bid to be regarded as the party of moral probity against the Conservatives' growing reputation for 'sleaze'; and the retrieval of the heritage of ethical socialism as alternative to dogmatic State centralism. It was about articulating alternatives to individual morality and emphasis on personal freedom (Thatcher) in favour of the recovery of the language of 'common good' as the language of empowerment of grass-roots citizenry.

${ }^{10}$ Blair, Tony (1993), Foreword. In Reclaiming the Ground: Christianity and Socialism ed. Chris Bryant, London: Spire, 9-12, p. 11. 
At the same time, religion was assuming a new visibility in public life in the UK. Throughout the twentieth century, the role of religion or questions of Church and state had steadily diminished as matters of political significance, and it did appear as if religious controversy was diminishing as grounds for public debate. Yet this began to change in the UK with the so-called 'Rushdie affair' of 1989, in which British Muslim groups took to the streets in protest at the publication of what they regarded as scurrilous misrepresentations of Islam in the book The Satanic Verses. The emergence of such a concerted and politicised Islamic movement onto the political scene exposed dramatically the fault-line in classical liberal opinion between support for freedom of expression and toleration of cultural diversity. Since then, and since 9/11, there has been a modest but significant proliferation of cases involving religious groups clashing with mainstream liberal public opinion: Sikh protests against the play Behzti, which was critical of abuses of power in a gurdwara; the well-orchestrated campaigns of the group Christian Voice against the screening on national television of Jerry Springer: the Opera; attempts by Roman Catholic Bishops to influence legislation on same-sex parents' adoption entitlement; mobilisation of conservative Christian groups to reform the abortion laws, and so on.

This is not to suggest that Britain is experiencing a religious revival. The continuing decline in institutional Christianity throughout Europe and certainly in the UK is undeniable, although much current debate in the sociology of 
religion is focused on the extent to which religion endures as a vestigial but influential cultural force through disaffiliated forms of religious practices and new spiritualities, ${ }^{11}$ and how decline is tempered by the growth of British Islam and the vitality of some minority Christian groups due to the presence of migrants from Africa, the Caribbean and Eastern Europe.

So at a number of levels, we have been witnessing contradictory trends. There is a new prominence of matters of faith within the public sphere, not just in the rhetoric of individual politicians and the processes of government policy, but as religion influences aspects of law, economics, welfare and citizenship. On the other hand, however, despite the continued existence of national established churches in England and Scotland, the nature of British public debate has tended to fight shy of 'doing God' in public, a diffidence which extends throughout the political culture.

\section{On not doing God}

By his second term, Blair's earlier willingness to discuss his faith appeared to give way to a greater ambivalence about religion. Possibly he was bruised by his

${ }^{11}$ Garnett, J., Grimley, M., Harris, A., Whyte, W., and Williams, S. eds (2006), Redefining Christian Britain: Post 1945 Perspectives. London: SCM Press. 
association with George W. Bush and jibes about them praying together; or perhaps he was reluctant to be identified with religion in the face of what might be termed the 'new secularism' amongst sections of the intelligentsia such as Richard Dawkins, Polly Toynbee or Christopher Hitchens.

For example, in the spring of 2003, when the allies were preparing to invade Iraq, some sections of the British media claimed that those close to Tony Blair had advised him not to end a televised address by saying, "God bless you" on the basis that viewers would be alienated by its explicitly religious nature. Instead, he closed with the words, "thank you". ${ }^{12}$ Similarly, Alistair Campbell is famously reported to have intervened in an interview to prevent Blair answering a question about his religious beliefs, allegedly with the comment, "We don't do God". ${ }^{13}$ We might also think of the media attention occasioned by Tony Blair's remark that God would, ultimately, judge his decision to go to war with Iraq, when he appeared on the talk show Parkinson in March 2006. ${ }^{14}$ And most recently,

${ }^{12}$ Brown, Colin (2003), Daily Telegraph (4 May) online, http://www.telegraph.co.uk/news/main/jhtml?xml=news/2003/05/04/nblair04.xml [11 May 2007].

13 ibid.

${ }^{14}$ White, Michael (2006), 'God will judge me, PM tells Parkinson', Guardian (4 March), online, http://www.guardian.co.uk/frontpage/story/0 $, 1723164,00$. html $[11$ 
interviewed for a BBC TV series of retrospectives on his ten years in power, Blair offered the opinion that: '... you talk about [religion] in our system, and frankly, people think you're a nutter.' ${ }^{15}$ This seems to be confirmation that whilst in office Blair walked what Callum Brown calls 'a political and cultural tightrope'16 between an openness about his personal convictions and a reticence to expose his beliefs to public scrutiny for fear of misunderstanding or ridicule. ${ }^{17}$

Such diffidence about mixing religion and politics appears to have spread to some religious leaders. When challenged in an interview in the Guardian newspaper early in 2006 on his relative silence on moral questions, the Archbishop of May 2007]. When Parkinson asked Blair, “Does [religion] still inform your view of politics and of the world?" Blair replied, "Well I think if you have a religious belief it does, but it's probably best not to take it too far." Later, when Parkinson said, "So you pray to God when you make a decision like that?" Blair countered with, "Well, you know, I don't want to go into sermons ..." Brown, Callum (2006), '"Best not to take it too far": how the British cut religion down to size.' Opendemocracy.net (8 March), online, http://www.opendemocracy.net/xhtml/articles/3335.html [11 May 2007], p. 1. ${ }^{15}$ BBC Television, The Blair Years, 2 December 2007.

${ }^{16}$ Brown,"'Best not to take it too far"', p. 2.

${ }^{17}$ Brown,"'Best not to take it too far"', p. 2. 
Canterbury, Rowan Williams, questioned the assumption (often prevalent in sections of the conservative media), that it was the duty of religious leaders to provide moral leadership to the nation by making regular public pronouncements. ${ }^{18}$ Yet part of Williams' argument against this was that this only added further fuel to public stereotypes of him as "“comic vicar to the nation".'19 Clearly, the spire of St. Albion's casts a long shadow. Yet Williams also expressed considerable scepticism towards the Church's ability to command automatic moral authority amongst the public at large:

"I think there is a bit of a myth, if you like, that Religious Leaders - 'capital R capital L' - are, by their nature, people who make public pronouncements on morals." Williams parodies this position as, "'Why doesn't the archbishop condemn X, Y, Z?' Because that's what archbishops do, you know, they condemn things. They make statements, usually negative, condemnatory statements ...

I just wonder a bit whether, you know, when an archbishop condemns something, suddenly in, I don't know, the bedsits of north London,

${ }^{18}$ Rusbridger, Alan (2006), "“I am comic vicar to the nation”', Guardian, 21 ${ }^{\text {st }}$ March. In fact, Williams has spoken on a number of matters, including the nature of childhood in a consumerist society, the future of legislation on abortion and the morality of the invasion of Iraq.

19 ibid. 
somebody says, 'Oh, I shouldn't be having premarital sex', or in the cells of al-Qaida, somebody says, 'Goodness, terrorism's wrong, the archbishop says so. I never thought of that.' I'm not sure that's how it is."20

Williams is caught between a rock and a hard place. Conservatives and traditionalists expect him to 'speak out' authoritatively; but in a society which is functionally secular, the majority of people regard religion "as a very alien, very mysterious, rather malign force, which gives people ideas above their station" ${ }^{21}$ Even for the Established Church to speak into such a vacuum requires delicate negotiation, since any pronouncement could be mistaken as an attempt to colonize or monopolize the democratic process or to displace a rational, open field of discourse with an irrational and closed value-system. Williams' sensitivities seem consistent with a general perception of the marginalization of organized religion in Western culture, therefore, and the impossibility, or even desirability, of even religious leaders doing God, at least in public.

Indeed, many would argue that whilst Blair's 'shy and tangential'22 professions of faith or Williams' self-consciousness may be due in part to a sense of the public relations aspect of 'doing God', attempts to offer religious reasoning to public

20 ibid.

${ }^{21}$ ibid.

${ }^{22}$ Brown, '"Best not to take it too far"', 2006, p. 1 
debate are illegitimate since they breach basic principles of liberal democracy, which hold that religion and politics cannot mix. It is to this debate that I shall turn next.

\section{Religion, Secularism and Modernity}

It is a commonly held maxim of political liberalism that public debate should be underpinned by secular rather than religious principles. In some political settlements, such as the United States for example, this has meant the constitutional separation of Church and State. The classical position on this matter is expressed by the political philosopher Robert Audi when he argues that whilst in a healthy democracy the good citizen should 'try to contribute in some way to the welfare of others', ${ }^{23}$ in a culturally or religiously diverse society this will require any policy to be founded on principles available to all citizens, regardless of their personal convictions: 'the ethics appropriate to a liberal democracy constrains religious considerations ... because of its commitment to preserving the liberty of all' ${ }^{24}$ Even if political or policy debate concerns matters of ethical

${ }^{23}$ Audi, Robert and Wolterstorff, Nicholas (1997), Religion in the Public Square:

Debating Church and State. Lanham: Rowman and Littlefield, p. 16.

${ }^{24}$ ibid., p. 174. 
and moral significance - such as abortion, stem-cell research, euthanasia, civil partnerships, even going to war - no publicly stated political discourse should rest on principles that are only accessible to a partial section of the community.

Yet increasingly, such a separation is coming into question, on empirical as well as philosophical grounds. For a start, questions are raised about the selfsufficiency of the secular to furnish the public domain with sufficiently robust values for consensus. In what has been termed the "Böckenförde dilemma", named after German Supreme Court justice Ernst Wolfgang Böckenförde, it is stated thus: "The liberal secular state lives from sources it cannot guarantee itself." ${ }^{25}$ In other words, something which claims to be value-free in itself cannot summon the necessary basis for diverse communities and institutions to articulate a commitment to broad-based participation.

An alternative view argues that only if citizens, each from their own deep convictions, and on the basis of an overlapping consensus on basic human rights, engage in public debate on the basis of a more humane society, will a vibrant civil

25 „Der freiheitliche, säkularisierte Staat lebt von Voraussetzungen, die er selbst nicht garantieren kann.“ (Böckenförde, Ernst-Wolfgang (1967), Sükularisation und Utopie. Ebracher Studien. Ernst Forsthoff zum 65. Geburtstag, Stuttgart, p.93.) 
society and a healthy democratic process be fostered. In response to Robert Audi's perspective, therefore, Nicholas Wolterstorff questions whether the freedom of the citizen in a liberal democracy necessarily has to involve the effacement of religious reasons in public debate. ${ }^{26} \mathrm{He}$ argues against their 'bracketing out' since he believes that to require religious constraint of others amounts to a restriction upon their freedoms and civil liberties as equal citizens. Wolterstorff continues, 'I see no reason to suppose that the ethic of the citizen in a liberal democracy includes a restraint on the use of religious reasons in deciding and discussing political issues' ${ }^{27}$ In addition, it would be unrealistic for those with religious principles to leave them out of the picture, since 'there is no prospect whatsoever . . of all adherents of particular religions refraining from using the resources of their own religion in making political decisions' ${ }^{28}$ If religious persons have religious reasons, it would be impossible not to include these, since 'we cannot leap out of our perspectives'.$^{29}$ There are no grounds for believing that a policy or piece of legislation will carry greater support on the grounds that religious reasons have been left out of the debate. ${ }^{30}$

\footnotetext{
${ }^{26}$ Audi and Wolterstorff (1997), Religion in the Public Square. pp. 111-112.

27 ibid., pp. 111-112.

28 ibid., pp. 11-12.

${ }^{29}$ ibid., p. 113.

30 ibid., p. 3.
} 
Such a segregation of religion and politics represents a 'strong' form of secularism in which all partisan values and principles, especially theologically-derived, are to be insulated from the public domain. Arguably, however, such a distinction could actually militate against any kind of public transparency. Neither secular states nor secularist public rhetoric are necessarily a protection against religiouslymotivated politics - quite the opposite, in fact - if a residue or minority of religious parties takes on a mission of actively shaping political or civic agenda.

Historically speaking, it may not even be a particularly accurate representation of the emergence of Western modernity and resulting settlements over the separation of Church and State. Stephen Toulmin argues that there never was such a polarization between 'secular humanism' and 'Christian orthodoxy': many of the early modern scientists and political theorists were devout believers, and the introduction of principles of free speech and tolerance were never intended to exclude religious reasoning from public debate. ${ }^{31}$ An Enlightenment critique of religious authoritarianism and the compulsory conjunction of Church and State and thus the enforcement of mandatory religious affiliation - should not be confused with the total redundancy of all religion. As Jose Casanova argues, 'secularization' in that respect was about the 'emancipation' of the secular from

${ }^{31}$ Toulmin, Stephen (1990), Cosmopolis: The Hidden Agenda of Modernity. Chicago: University of Chicago Press, pp. 24-25. 
the religious, but willed as much in the name of religious freedom as the wish to see the end of all religion..$^{32}$

What we need is an analysis that enables the co-existence of the facts of religious decline with the public visibility of religion in its many guises. Casanova has been critical of those versions of secularization theory which conceive the process of secularization as the inevitable and inexorable disappearance of religious beliefs and practices in the modern world. He questions such versions of the secularization thesis on both normative and empirical grounds, arguing that they simply perpetuate 'a myth that sees history as the progressive evolution of humanity from superstition to reason, from belief to unbelief, from religion to science.' This mythical account of secularization, says Casanova is itself in need of 'desacralization'.33

For purposes of greater clarity, Casanova has therefore identified what he regards as three main dimensions of the phenomenon of secularization: firstly, the decline of religious institutions, secondly, the separation of religion and the State or

\footnotetext{
${ }^{32}$ Casanova, José (2006), 'Rethinking secularization: a global comparative perspective'. The Hedgehog Review Spring/Summer, 7-22.

${ }^{33}$ Casanova, José (1994), Public Religions in the Modern World. Chicago: University of Chicago Press, p. 17.
} 
differentiation of religious and secular organizations and thirdly, the 'privatization' of religion. These are largely independent variables, so it would be possible to see each of these features taking a different course in any particular society. Thus, it could be argued that in Britain, a model may be emerging of partial secularization in terms of decline and differentiation, but not of 'privatization' - indeed, that given the trends outlined above it may be necessary to speak of the 'deprivatization of modern religion' ${ }^{34}$ It also means that the best way of conceiving society - and therefore the nature of public discourse - might be certainly 'post-Christian' in that the authority of the Church and Christian culture are no longer predominant, but also 'post-secular' in that religious pluralism and the persistence of various kinds of practice and affiliation endure not simply as private options but as public realities.

The end result of this would be a society in which there was a divergence between a religiously indifferent (but not necessarily hostile or secularist) majority, and a series of religiously-orientated minority groups. The latter would represent a wide range of opinion, from broadly supportive of the liberal pluralist agenda to those who strategically campaigned against specific pieces of legislation or cultural mores - such as abortion, blasphemy laws or civil partnerships - to those who were more virulently opposed to Enlightenment liberal values.

${ }^{34} \mathrm{i}$ bid., p. 215. 
The deficiencies of much of the dominant drift of social scientific analyses of religion may however call for new tools and conceptual frameworks by which to examine phenomena such as New Labour's use of religious and moral discourse. Without departing from his central thesis of the irrevocable secularity of British society, the historian Callum Brown has called for a renewal of theoretical and empirical tools by which to evaluate the cultural and political currency of religion, not least because instances of exceptionalism or resistance to such a trend are of sufficient significance to occasion reappraisal of some of the established methods of analysis..$^{35}$

But one major thing needed is a workable narrative with which to tell the story of religion in the wider context of culture, politics and society. A new world order has been invoked in which, like it or not, religion is being restored after a long gap as a defining category of analysis. Having written religion out, it is not necessarily going to prove easy to reinsert it. ${ }^{36}$

\footnotetext{
${ }^{35}$ See also Brown, Callum (2007), 'Secularization, the growth of militancy and the spiritual revolution: religious change and gender power in Britain, 1901-2001', Historical Research, 80, No. 209, 393-418.

${ }^{36}$ Brown, ibid., p. 394.
} 
This moves us on, therefore, to consider what theoretical and analytical perspectives may be available to scholars and commentators in trying to gain critical purchase on the resurgence of religion in the public domain.

\section{Doing God in Public: an Agenda for debate}

We are looking, therefore, for explanatory theories that enable that 'gap' to be rectified - the gap being, in Callum Brown's terms, the absence of religion from public debate and social analysis. It might require elements of discernment over the exercise of some degree of public accountability, such as when religious groups are in receipt of public funding; a measure of understanding from the inside what motivates religious groups and individuals; a means of critiquing, from a theologically-informed vantage-point, how religious rhetoric is functioning in the public statements of political leaders.

What follows is a brief review of some possible perspectives.

\section{Reconfiguring the public and the private}

As we have seen, the demand that citizens in a liberal democracy must only use secular arguments in public discussion was contingent upon a particular configuration of modernity in the West. But strategically, the further danger is 
that such an insulation of public from private inhibits the extent to which any critical or rational scrutiny can be exercised over the activities of religious groups. It attenuates our capacity to examine the religious and theological foundations of public policy or political discourse. Intriguingly, of course, whereas the roots of such privatization of religion may have been motivated by a wish to protect religious minorities against a dominant majority which also defined itself theologically or ecclesiastically, the contemporary position in the West is to protect the rights of a non-affiliated majority against perceived breaching of a liberal consensus on the part of religious minorities. That may also require us to revisit the question of how the neutral or non-confessional public sphere is regulated.

Greater clarity on this dilemma may be brought if we distinguish between two different types of secularism. Sunder Katwala contrasts 'ideological' secularism with 'pragmatic' secularism which values the rights of all citizens but refuses to discriminate on the grounds of religion, just as it seeks to respect diversity of gender, sexuality and ethnicity. ${ }^{37}$ This means it must respect the prerogative of religious participants to advance religious views in public. Rowan Williams has recently made a similar distinction between what he terms 'programmatic' and

\footnotetext{
${ }^{37}$ Katwala, Sunder (2006), 'Faith in democracy: the legitimate role of religion.' Public Policy Research December-February, 246-251.
} 
'procedural' secularism. Whilst programmatic secularism suspends any talk of value in a semblance of instrumental neutrality, procedural secularism engages with but attempts to adjudicate between, competing convictions:

It is the distinction between the empty public square of a merely instrumental liberalism, which allows maximal private licence, and a crowded and argumentative public square which acknowledges the authority of a legal mediator or broker whose job it is to balance and manage real difference. The empty public square of programmatic secularism implies in effect that the almost value-free atmosphere of public neutrality and the public invisibility of specific commitments is enough to provide sustainable moral energy for a properly self-critical society. But it is not at all self-evident that people can so readily detach their perspectives and policies in social or political discussion from fundamental convictions that are not allowed to be mentioned or manifested in public. ${ }^{38}$

Similarly, Jose Casanova argues for the persistence of religiously-motivated influences in the public sphere, and endorses the continuity of faith-based organizations' contribution to public life, so long as they are capable of acknowledging the pluralist nature of society. If religions react constructively to

38 ibid. 
differentiation, if they do not work against the modern individual freedoms Casanova argues - they can become legitimate public voices.

Although it takes us beyond the scope of this volume, this is an important implication of the recovery of religious dimensions to political life. It is all very well for religious groups to bring their convictions into the debate, but this implies that they already accept the terms of pluralist and public discourse as an appropriate ethic. However, the eruption of some counter-cultural religious groups has been on the basis of refusing to recognise such a compromise. But the problem is when some faith groups expect to enter the political arena to state public claims on the basis of private commitments. ${ }^{39} \mathrm{I}$ wonder, therefore, whether it is possible to move towards a consensus that is capable of differentiating between these three categories, respecting that what is contained within them requires translation into a common civil discourse that is not so much 'neutral' as 'mediated'.

\section{Faith as public praxis}

So far, we have concentrated on the public pronouncements of public figures and religious leaders, but we should not neglect a major area in which the moral and

${ }^{39}$ See Neuhaus, Richard (1984), The Naked Public Square: Religion and democracy in America. Grand Rapids, MI: Wm. B. Eerdmans, p. 36. 
religious dimensions of public life are already active. This concerns the practical interventions of faith-based organizations, as part of local and national civil society. Faith-based organizations continue to exercise a significant influence in public life as political interest groups, as providers of social welfare, education and community services and they are increasingly being invited to consider themselves as an active and essential part of the 'third sector' of community and voluntary organizations and encouraged to participate in projects of welfare provision, neighbourhood regeneration, education and other forms of service delivery. ${ }^{40}$

The "third sector" comprises non-governmental organisations which are value-driven and which principally reinvest their surpluses to further social, environmental or cultural objectives. It includes voluntary and community organisations, charities, social enterprises, cooperatives and

${ }^{40}$ Farnell, Richard et al (2003), 'Faith' in Urban Regeneration: Engaging Faith Communities in Urban Regeneration. Bristol: Polity Press; Timmins, Nicholas (2007), '"Bigger Role" for private sector in welfare-to-work.' Financial Times (14 February), online, http://www.ft.com/cms/s/8bf51726-bbd0-11db-afe4-0000779e2340.html [accessed 27/06/07] 
mutuals. Faith groups also play a very important role. The third sector is large and growing, and plays an increasingly vital role in both society and economy. ${ }^{41}$

In terms of New Labour's ambitions for welfare reform, faith-based organizations are regarded as rich in social capital, embodying the virtues of localism, altruism and community spirit. Indirectly, therefore, rather than fracturing the body politic, faith-based organizations are viewed as one means of enhancing social cohesion, and it is another contributory factor to the 'new visibility' of religion with a distinctively local, practice-based flavour. ${ }^{42}$

Others sound notes of caution or criticism, however. First, of course, is the view already debated that religion has no legitimate place in the public domain, and certainly not in the delivery of essential welfare services. The assumption that faith is a reasonable and liberal set of values which engenders good citizenship

\section{${ }^{41}$ (http://www.hm-}

treasury.gov.uk/documents/public spending reporting/charity third sector.html (accessed 14/06/07)

${ }^{42}$ Farnell, Richard, et al. (2003), "Faith" in Urban Regeneration? Furbey, Rob (1999), 'Urban "regeneration": reflections on a metaphor', Critical Social Policy 19:4, 41945. 
and social cohesion is repudiated. The Cantle report on urban riots in Northern English cities in 2001, for example, spoke of communities living parallel but separate lives, of religion as a divisive rather than cohesive force. And of course any faith-group or interest group may be very effective at delivering services to its own constituency - in what would be termed 'bonding' social capital - whilst being indifferent to extending beyond its own boundaries.

Further studies of how faith-based organizations actually negotiate questions of public funding and accountability, therefore, might reveal more information on how the particular values of a religious tradition are mediated into the public domain in practice. Are there common values around neighbourhood renewal, social welfare, protection of the vulnerable, or local capacity-building which might form the 'pragmatic' basis of a shared praxis of realising the common good?

\section{Fostering 'religious literacy' in public life}

One person who has spoken of the need for new sensibilities for public discourse in a 'post-secular' society is Jürgen Habermas, most famously in his acceptance 
speech for the German peace prize in $2001 .{ }^{43}$ This followed on from a short monograph on bioethics in which he considered the contribution of religious values to concepts of human dignity ${ }^{44} \mathrm{He}$ appears to be developing a new interest in the possibility of those who combine faith and reason to have some measure of contribution to make on matters of value. This joins with the voices of Williams, Casanova, Katwala and others, surveyed above, who conceive of a 'pragmatic' secularism which avoids privileging either religious or secular perspective, but seeks to engage them in shared debate in a conversational or communicative process. Such a model of debate seeks to 'honour the important public role of religion as a nurturer of reason and moral formation, while at the same time maintaining the religious impartiality of the state necessary for a pluralistic democracy.'45

${ }^{43}$ Habermas, Jürgen (2001), Glauben und Wissen. Frankfurt am Main: Suhrkamp. See also Harrington, Austen (2007), 'Habermas' Theological Turn?' Journal for the Theory of Social Behaviour 37:1, 45-61.

${ }^{44}$ Habermas, Jürgen (2003), The Future of Human Nature. Cambridge: Polity Press.

${ }^{45}$ Bedford-Strohm, Heinrich (2007), 'Nurturing Reason: the public role of religion in the liberal state'. Ned Geref Teologiese Tydskrif 48, 1 \& 2, March-June, 2541, p. 35 . 
Yet arguably we still need more concerted attention to the actual workings of religious discourse in shaping the moral and political outlooks of varied protagonists in the public domain. Here, the work of the British practical theologian Stephen Pattison may be helpful. Pattison is concerned with the relationship between ethics and organizations, and the search to develop a critical theory of corporate values. He is interested in the way 'secular' discourses and organizations bear many of the characteristics and functions of religion; not necessarily in terms of formal systems of moral guidelines, but in the form of the narratives, secular rituals or goals to which an organization subscribes and which constitute its corporate identity. ${ }^{46}$ This seeks to offer a degree of 'religious literacy' to the public domain, by examining the theological roots of appeals to public and corporate values and subjecting them to critical scrutiny. Pattison's aim is to equip people 'as critical "theologians" of their own inhabited worldviews ... to become critics of their faith positions' ${ }^{47}$

Pattison argues that all organizational cultures carry appeals to more than just instrumental or pragmatic reasoning. He argues that this is not just of sectarian concern to those formally attached to religious bodies, but for all those involved

${ }^{46}$ See especially, The Challenge of Practical Theology (London: Jessica Kingsley, 2007), Part 1: Ethics and Values and Part 2: On Organization and Management. ${ }^{47}$ ibid., p. 69. 
in forging and implementing policy and service delivery. Theology has the capacity to identify, analyze and challenge the 'myths' by which people live; yet also it contends that the stories and symbols circulating throughout our public and institutional life are essential elements of culture, even though they may be deluded or life-affirming. 'Rather than live without faith and beliefs of any kind,' says Pattison, 'the point is for us to recognize and critically assess our inhabited systems of faith, our beliefs, and our rituals. ${ }^{\prime 48}$

This approach could be harnessed as a critical tool to systematize people's implicit value-commitments, as embodied in their managerial and organizational practices, thereby making explicit the relationship between the values people hold and the behaviours they engage in. In this respect, he stands in a longer tradition of those who seek to excavate the implicitly religious values at work in secular institutions and conventions, such as Max Weber or Paul Halmos. ${ }^{49}$

I wonder whether such a critical perspective might be put to work not only in relation to corporate institutions' 'mission statements' but the public

${ }^{48}$ Ibid., p. 80.

${ }^{49}$ See Pattison, S. (1997), The Faith of the Managers: when management becomes religion. London: Cassell. Halmos, P. (1965), The faith of the counsellors. London: Constable. 
pronouncements of political leaders like Tony Blair. To end, therefore, I have selected recent public statements by two rising politicians who have a personal Christian commitment yet are mindful of how best to reconcile openness about their own political and moral motivations with sensitivity towards a pluralist public realm.

Kevin Rudd, elected Prime Minister of Australia in November 2007, went against the grain of predominantly secularist public debate in that country ${ }^{50}$ when still leader of the opposition in 2006, by writing about the connections between faith and politics. This was more than a personal confession of faith, however, being quite overtly party-political in criticising what Rudd called 'the political orchestration of various forms of organised Christianity in support of the conservative incumbency' on the part of George W. Bush in the U.S. and John Howard in his own country. ${ }^{51}$ Rather than bolstering the interests of the powerful within a conservative programme that stresses family values and personal morality at the expense of social justice, Rudd argues that the instincts of Christianity are prophetic and counter-cultural. He regards Dietrich Bonhoeffer as

50 See Maddox, Marion (2007), Religion, Secularism and the Promise of Public Theology. International Journal of Public Theology 1:1, 82-100.

${ }^{51}$ Rudd, Kevin (2006), 'Faith in Politics'. The Monthly (October) online, http://www.themonthly.com.au/excerpts/issue17 excerpt 001.html, p.5 [12/06/07] 
a potential role-model for those seeking an alternative model of political engagement, and hints that in a secular pluralist world Christianity may move more towards 'a counterculture operating within what some have called a postChristian world'. ${ }^{52}$

This is not a bland homily. Rudd is invoking theology to deliver a sustained attack on his rival, John Howard, but his argument is developed via a detailed engagement with Bonhoeffer's political theology of speaking truth to power and the Biblical principle of the preferential option for the poor. Yet one of the lynchpins of Rudd's attack on Howard is the latter's attempt to construct a discourse of Australian national identity premised on a 'clash of civilisations' which Rudd regards as implicitly anti-Islamic. ${ }^{53}$

A Christian perspective on contemporary policy debates may not prevail. It must nonetheless be argued. And once heard, it must be weighed, together with other arguments from different philosophical traditions, in a fully contestable secular polity. A Christian perspective, informed by a social gospel or Christian socialist tradition, should not be rejected contemptuously by secular politicians as if these views are an unwelcome

\footnotetext{
${ }^{52}$ Rudd, 'Faith in Politics', p. 3.

${ }^{53} \mathrm{i}$ bid., p. 10
} 
intrusion into the political sphere. If the churches are barred from participating in the great debates about the values that ultimately underpin our society, our economy and our polity, then we have reached a very strange place indeed..$^{54}$

When Barack Obama, the U.S. Democratic presidential candidate, was asked what he had been reading recently in an interview with The New York Times, he quoted the unlikely choice of the liberal Protestant public theologian and ethicist Reinhold Niebuhr. Whilst public discourse and political campaigning in the U.S. especially for President - is altogether more comfortable with public professions of faith than Australia or the UK, the Democrats have struggled in the past to capture the religious vote and have fought shy of campaigning on 'Christian moral values'. Yet here is a politician whose political roots are in church-related broad-based organizing in Chicago, and who announced his candidacy on the steps of his local church. It is of course possible that he knew the question was coming in advance of the interview, but it is still significant that he chooses to indicate an interest in the moral legacy of twentieth-century Christian Realism for contemporary international politics. When asked what he takes away from his reading of Niebuhr, Obama's answer is once again superficially measured but is of course directed against his political opponents both within and beyond his own

${ }^{54}$ ibid., p. 7 
party, with particular censure aimed at those who allow an excessively doctrinaire world-view to inform their political decisions:

I take away ... the compelling idea that there's serious evil in the world, and hardship and pain. And we should be humble and modest in our belief we can eliminate those things. But we shouldn't use that as an excuse for cynicism and inaction. I take away the sense we have to make these efforts knowing they are hard, and not swinging from naïve idealism to bitter realism. ${ }^{55}$

Both are examples, I contend, of deliberate attempts to communicate across gulfs of religious and moral pluralism into a shared public discourse in ways which manage both to respect the pluralism of their intended audience without selling short these politicians' integrity. In neither case, either, did the theological sources diminish the sharply political intentions of such statements!

${ }^{55}$ Brooks, David (2007), 'Obama, Gospel and Verse' The New York Times (26 April), online, http://select.nytimes.com/search/restricted/article?res=FA0810FD3E5A0C758EDD A $[12 / 06 / 07]$. 


\section{Conclusion}

One characteristic of British society over the past decade has been how controversial and sensitive the reintroduction of religion into public life has become, whether that is measured in terms of the personal values of a new generation of conviction politicians, the pronouncements on current affairs by established faith leaders, or the political mobilization by particular religious bodies in order to influence public opinion.

Within all this, once again, is the vexed question of what legitimacy religion and religious identity should play within any such debate. It is no longer about the primacy of one, Established, Christian tradition as definitive of national identity and the moral basis of something called 'the common good', and nor is it any longer a matter of evacuating matters of religious belief and affiliation from public life and civil society altogether. It is, perhaps, a matter of articulating a new settlement within a population that comprises a majority of people largely indifferent but not hostile to organized religion, alongside a small but increasingly self-conscious and well-mobilised minority made up of a heterogeneity of religious groups.

I stated at the beginning of this paper that it wasn't about Tony Blair, and in one sense it isn't. But in other ways, of course it is. Of course it is, given our fascination 
with political figures and celebrities. On one hand, with Blair's departure - which this conference was called to mark - we are seeing the end of an era, where the enduring significance of one man's personal values will be subjected to the hindsight of posterity. On the other, however, it is also undeniable that religion and morality have featured significantly as part of the 'soul' of New Labour, and so further interrogation is necessary in order to gain a better sense of the coherence of such values and the reasons for their deployment, and as a casestudy of what legitimacy there may be in 'doing God' in public. This volume seeks to encourage these debates. 